\title{
Women Entrepreneurship in Romania: A Regional Evaluation
}

\author{
Cristina Bianca POCOL ${ }^{1 *}$, Călin MOLDOVAN-TESELIOS ${ }^{2)}$ \\ ${ }^{1)}$ Faculty of Horticulture, University of Agricultural Sciences and Veterinary Medicine of Cluj Napoca, \\ 3-5, Mănăștur Street, Cluj Napoca, Romania. ${ }^{2}$ Metro Media Transilvania, Cluj Napoca, Romania. \\ ${ }^{*}$ Corresponding authors, e-mails: cristina.pocol@usamvcluj.ro
}

Bulletin UASVM Horticulture 71(2) / 2014

Print ISSN 1843-5254, Electronic ISSN 1843-5394

DOI:10.15835/buasvmcn-hort:10607

\begin{abstract}
The study aims to asses overall satisfaction of the initiative for becoming an entrepreneur among women in Romania. The research was conducted in the Regions of North East, North West and West, on a sample of 602 women entrepreneurs. The research method chosen was the sociological survey. Almost three quarters of the respondents declare to be satisfied having opened a business. The degree of satisfaction regarding this decision is associated with age, education and family income. The main motivations identified are: capital accumulation, independence, lack of employment or the rise of an opportunity. Most frequently, women entrepreneurs feel respect due to their status, this decreasing among those with secondary education, with family incomes below 3000 RON and those who don't have employees.
\end{abstract}

Keywords: entrepreneurship, necessity, opportunity, satisfaction, women

\section{INTRODUCTION}

The involvement of women in entrepreneurship varies from one country to another and from one region to another, being influenced mainly by the cultural differences, by the perception of the society on the role of women in the economy and by access to the labour market (Global Entrepreneurship Monitor, 2013). GEM 2013 Women's Report reveals the existence of 126 million women who have started a business in 67 economies all around the world. Besides, there were 98 million women who run a stable business, the main benefit for the economy being the creation of new work places (Global Entrepreneurship Monitor Women's Report, 2013). According to the same study, in Pakistan, women entrepreneur represented only $1 \%$ of female population, while in Zambia, the percentage was of $40 \%$. The highest number of women actively involved in entrepreneurship was found in Sub-Saharan Africa (27\%), in Latin America and the Caribbean $(15 \%)$, while the lowest share could be found in developed economies from Europe and Asia (4-
5\%) (Global Entrepreneurship Monitor Women's Report, 2013).

Female entrepreneurship is considered by scholars one of the most creative and innovative areas (On, 2011). Traditional approaches of researches conducted in this field were based, generally, on the following aspects (Hughes et al., 2012): comparing the performance of companies led by women versus those managed by men, by identifying the percentage of women involved in entrepreneurial activities in different countries, comparing the manner in which men and women construct the notions of "entrepreneurship" and "development". The same authors (Hughes et al., 2012) considered to be necessary the identification of new research lines that would examine the relationship between women's entrepreneurial experience and their family life, to compare the way in which women and men exploit entrepreneurial opportunities and to analyse the reconstruction in time and space of linkages between women and men, created by entrepreneurship. The latest researches (Jennings 
and Brush, 2013; Achtenhagen and Tillmar, 2013) on female entrepreneurship fully confirm the direction anticipated by Hughes. To these are added some new ones, such as identifying the resources that contribute to the success of businesswomen, studying the underlying motivations for women starting a business, the influence of social and political constraints on women entrepreneurs, the influence of the residential environment (rural versus urban) on women's entrepreneurial behaviour as well as the impact of the economic crisis on the creation of new businesses by women. In Japan, the business segment led by women is growing; the main resources that contribute to their success relying on the advice and recommendations offered by the government and by private agencies (Welsh et al., 2014). In Saudi Arabia, family and friends are the ones giving advice in decision making by women entrepreneurs (Welsh et al., 2014). Studying the underlying motivations to start a business primarily reveals pecuniary issues. In Venezuela, the desire to be your own boss and the income growth represent the main factors behind women's entrepreneurship (Zimmerman and Chu, 2013). In Northern Ireland, women entrepreneurship is motivated by the desire to balance gains and work responsibilities with family commitments (McGowan et al., 2012).

As for the socio-political constraints, studies conducted in Israel reveal significant differences between women belonging to the majority population, to minorities and to immigrants (Heilbrunn et al., 2014). Rural residency may be another factor to influence female entrepreneurship. Vosta and Jalilvand (2014) show the importance of social capital - structural, relational and cognitive - on the success of rural businesswomen. The influence of global economic crisis on female entrepreneurship has been tested by Paul and Sarma (2013) in 30 countries in Eastern Europe and Central Asia, the results showing the fact that for the population studied, the crisis acted as a catalyst for starting a business.

This study was conducted within the project POSDRU entitled "An Integrated Intervention in order to strengthen social entrepreneurship among vulnerable women" implemented in 20102013. Exploring women business experience, the research aimed to assess their satisfaction towards the initiative of becoming entrepreneurs and for understanding the context, the motivations, the barriers and the inner universe of women entrepreneurs.

\section{MATERIALS AND METHODS}

The research was conducted in the Regions of North East, North West and West of Romania, thus responding the exigencies of the project to create a stable, multiregional support mechanism, to cover three of the eight regions of the country for supporting women who intent to start a business. The research methods used for reaching the objectives of the study can be classified in two categories: for desk research there were consulted statistical data relevant for the objectives of the study and a bibliographic study was realized, while for the field research was used the sociological survey. The questionnaire was structured for women from all three regions who have already an entrepreneurship activity, including the following sections: general opinions regarding entrepreneurship, entrepreneurial activities, necessities for performing entrepreneurial activities and socio-demographic data.

There were interviewed 602 women entrepreneurs, 201 women entrepreneurs in the Regions of West, 201 women entrepreneurs in the Regions of North-West and 200 women entrepreneurs in the Region of North-East. The primary sample unit was the company. The selection of the companies was conducted randomly, from the data basis of Trade Register, including all companies registered, regardless of the legal form of incorporation. Then, a second selection followed, using the screening of companies in which the administrator, the owner or one of the associates was a woman. That person was later on interviewed by phone, between the 1 st and the 23rd of October 2013.

The sample was decided in rapport with the regional structure of the female entrepreneurs, as it resulted from the studies conducted by Global Entrepreneurship Monitor - GEM from the last 3 years $(2011,2012,2013)$. The socio-demographic structure of the sample, in rapport with age and education, is the following: maximum 40 years - $32 \%$, between $41-50$ years - $32 \%$, between 51 60 years - $26 \%$, over 60 years - $10 \%$; maximum 10 secondary education - 4\%, high school, postsecondary education - 33\%, university - $63 \%$.

The level of satisfaction of women entrepreneurs („How satisfied you are that you have 
decided to start a business on your own?") was measured through the ordinal Likert scale with five levels (Boone and Boone, 2012): level 1 "very satisfied", level 2 - "pretty satisfied", level 3 - "neither satisfied nor satisfied", level 4 - "rather unsatisfied" and level 5 - "very unsatisfied". The level of satisfaction was also evaluated by questioning women about the hypothesis of repeating the entrepreneurial experience: level 1 - "I would definitely decide to become an entrepreneur", level 2 - "I would probably decide to become an entrepreneur", level 3 - "I would probably decide not to become an entrepreneur", level 4 - "I would definitely decide not to become an entrepreneur" and level 5 - "I would postpone taking a decision".

Data were processed using SPSS Program, achieving correlations with the socio-demographic variables: age, education and income.

\section{RESULTS AND DISCUSSIONS}

Assessing the degree of satisfaction regarding the initiative of starting a business led to the following results: over $70 \%$ of the interviewed persons declared to be satisfied and very satisfied about the fact that they have become entrepreneurs, $12 \%$ were unsatisfied, the rest placing themselves in the middle of the classification (Fig. 1).

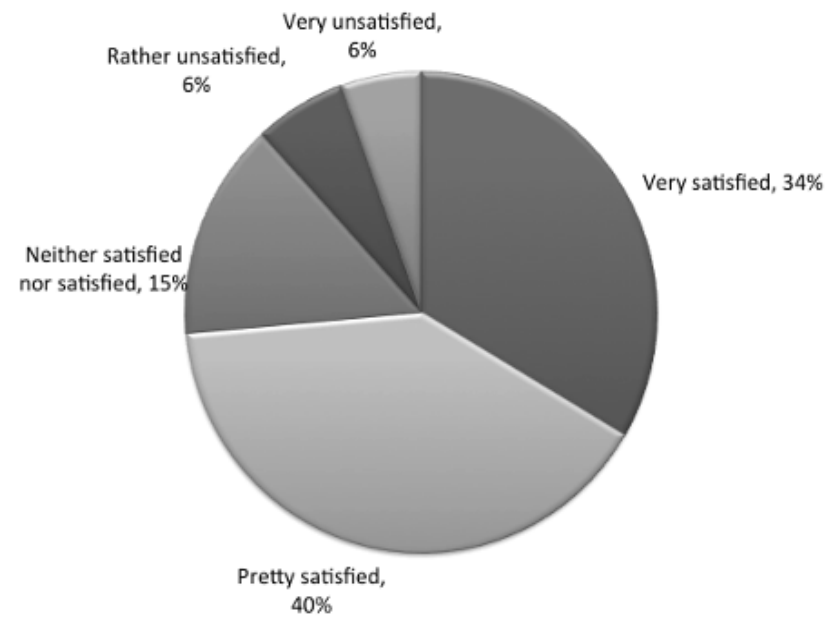

Fig. 1. „How satisfied you are that you have decided to start a business on your own?"

Correlating these results with the sociodemographic characteristics of the respondents, it can be seen a more balanced, weighted satisfaction in the Region of North East, among women entrepreneur without employees or those with over 10 employees. A more accentuated dissatisfaction, for all the regions included in the study, can be observed among women entrepreneurs with secondary education and family incomes under 3000 RON per month.

On the other hand, there are women with university studies and with family incomes of over $6000 \mathrm{RON} /$ monthly. The existence of a correlation between education and entrepreneurial activities has been identified by other studies in the specialty literature (Raposo and Do Paço, 2011), the role of education consisting not necessarily in gathering knowledge but, mostly, in changing attitudes regarding entrepreneurship. Most previous studies on female entrepreneurship indicate strong correlations between the satisfaction of running a business and generating additional incomes (Brush, 1999). This is confirmed also by the present study, the most satisfied women entrepreneurs being those who benefit from incomes that guarantee financial stability for the family.

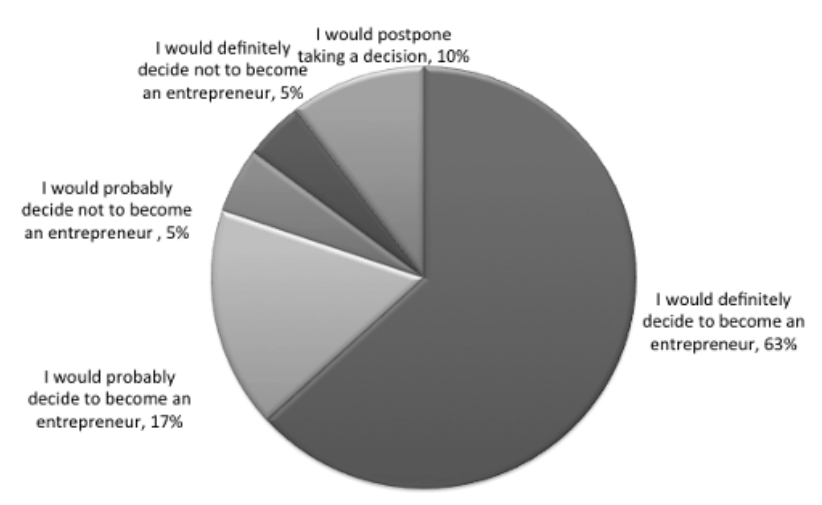

Fig. 2. „Regarding your decision to become an entrepreneur, if you had to relive it...?"

Another aspect taken into consideration was the regret or the satisfaction vis-à-vis the decision of becoming an entrepreneur (fig. 2). Thus, almost 2 thirds $(63 \%)$ of the respondents declared that they would definitely take the same decision if they had to decide to start a business. Other $17 \%$ would probably take the same decision and only $10 \%$ would definitely/most likely take the decision not to become an entrepreneur. The decision to repeat the experience of starting up a business is 
correlated with the family income, education and age. Repeating the decision to initiate a business is most frequent among women with high family incomes (> $6000 \mathrm{RON} /$ month), $91 \%$ of them being convinced that, if they had to relive the situation, they would take the same decision. In exchange, only $72 \%$ of the businesswomen with secondary education would repeat the initiative regarding a business. It seems that the level of education can influence the failure rate of start-up firms and the intellectual capital can be associated with the decision to repeat the entrepreneurial experience. The influence of education on the business performance was also examined by Pena (2002). The results of his study suggest that the human capital (education, competencies and motivations) plays a crucial role in the success of a business.

Women entrepreneurs of maximum 40 years are willing, available to a higher extent to repeat the decision compared with women aged between 41 and 60 years. The probability of repeating the decision to start a business is higher in the case of young people (they are perhaps more motivated, healthier and self-confident). The tendency toward younger entrepreneurs in the efficiency-driven economies is also confirmed by the results of Global Entrepreneurship Monitor (2013). According to GEM 2013, young people have "fresh ideas" and they are "born-digitals", in comparison with their parents. Older people have family responsibilities and they are not opened to repeat risky experiences.

The inclination towards entrepreneurship for older persons was studied by specialty literature in relation with social rules. Thus, if a community shares the opinion that age is not an impediment in starting up a business, this fact can have a positive impact on women entrepreneurs, encouraging women not so young to have such initiatives (Kautonen et al, 2011). Age as a determining factor in the success of a business has been debated also in other regional studies regarding female entrepreneurship (Akehurst et al, 2012). In Romania, the start-up of a business at older ages is not common, only $3 \%$ of the women interviewed having over 55 years when they started the business (Fig. 3).

Analysing the moment of the business startup is important in Romania due to the fact that this was possible starting only with 1990, after the fall of the communist regime. It has been observed that the share of women who have started a business increased slightly in the period 19902004, followed by a real boom between 2005 and 2008 and a significant decrease after 2009, due to the economic crisis (Fig. 4). In reality, the decrease recorded after 2009 is not significant, being amplified by the selection of companies from a data basis made in 2012 .

Contrary to the results of other studies (Paul and Sarma, 2013), the economic crisis did not play the role of a catalyst in the regions studied for business start-up by women, the fiscal constraints and the improper institutional context offering a possible explanation for this fact. Researches regarding the entrepreneurial behaviour of women from countries in transition show reveal the connection between an insecure, ambiguous and turbulent institutional context and entrepreneurship development (Welter and Smalbone, 2011). Regionally, having not noticed any significant differences between categories,

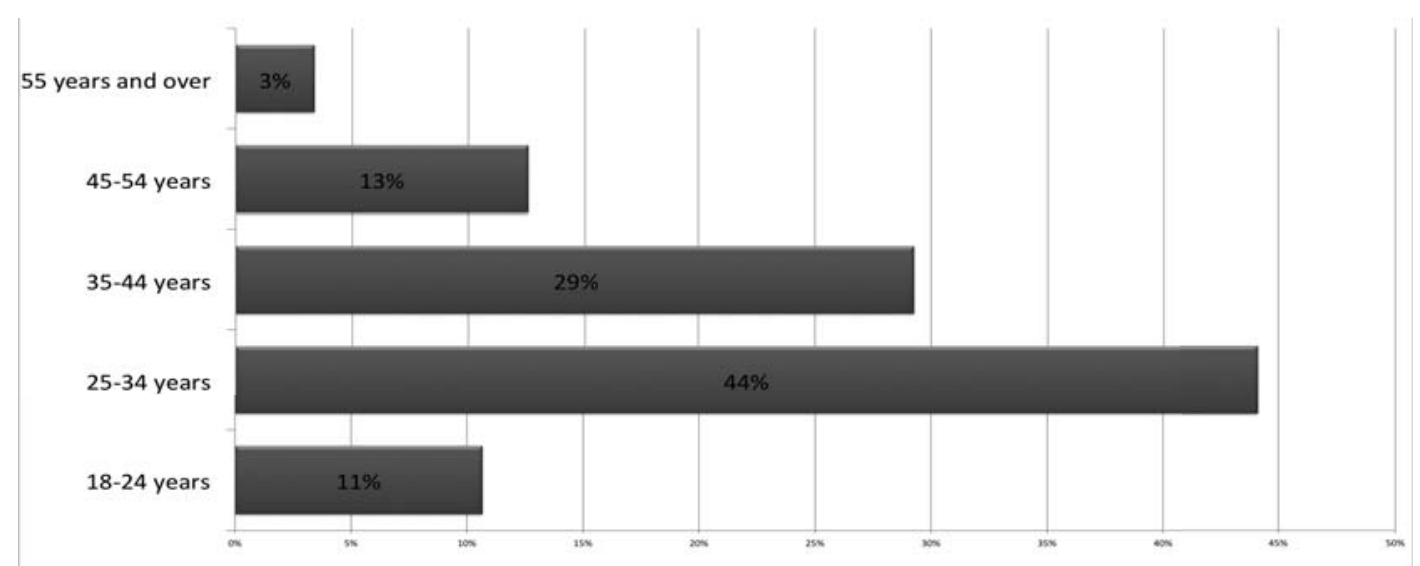

Fig. 3. „How old were you when you became an entrepreneur?” 


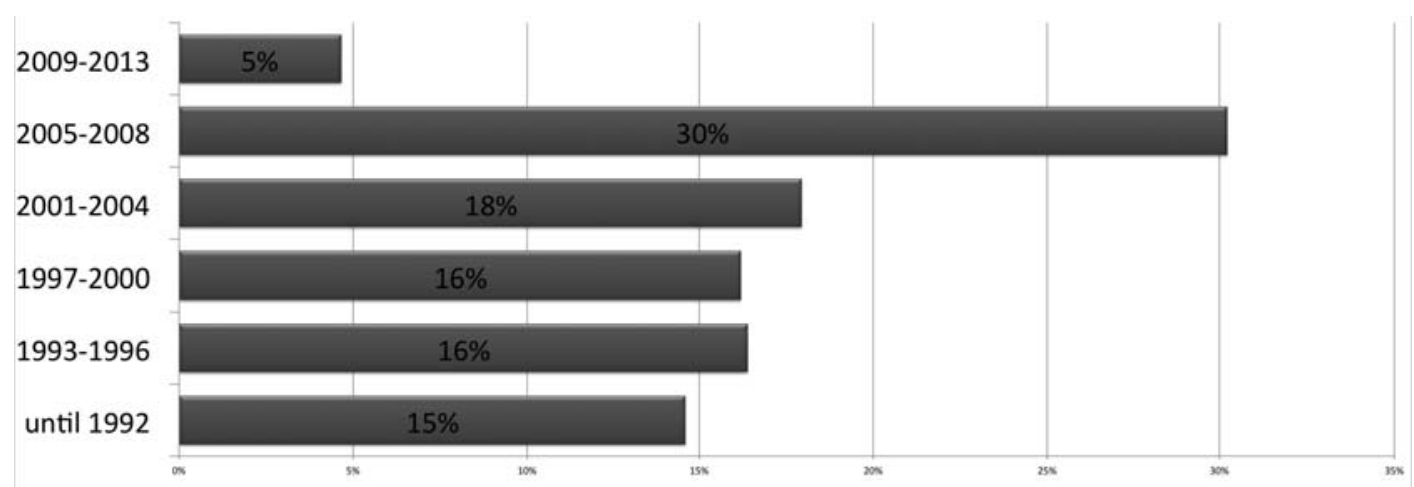

Fig. 4. „What year did you start the business?”

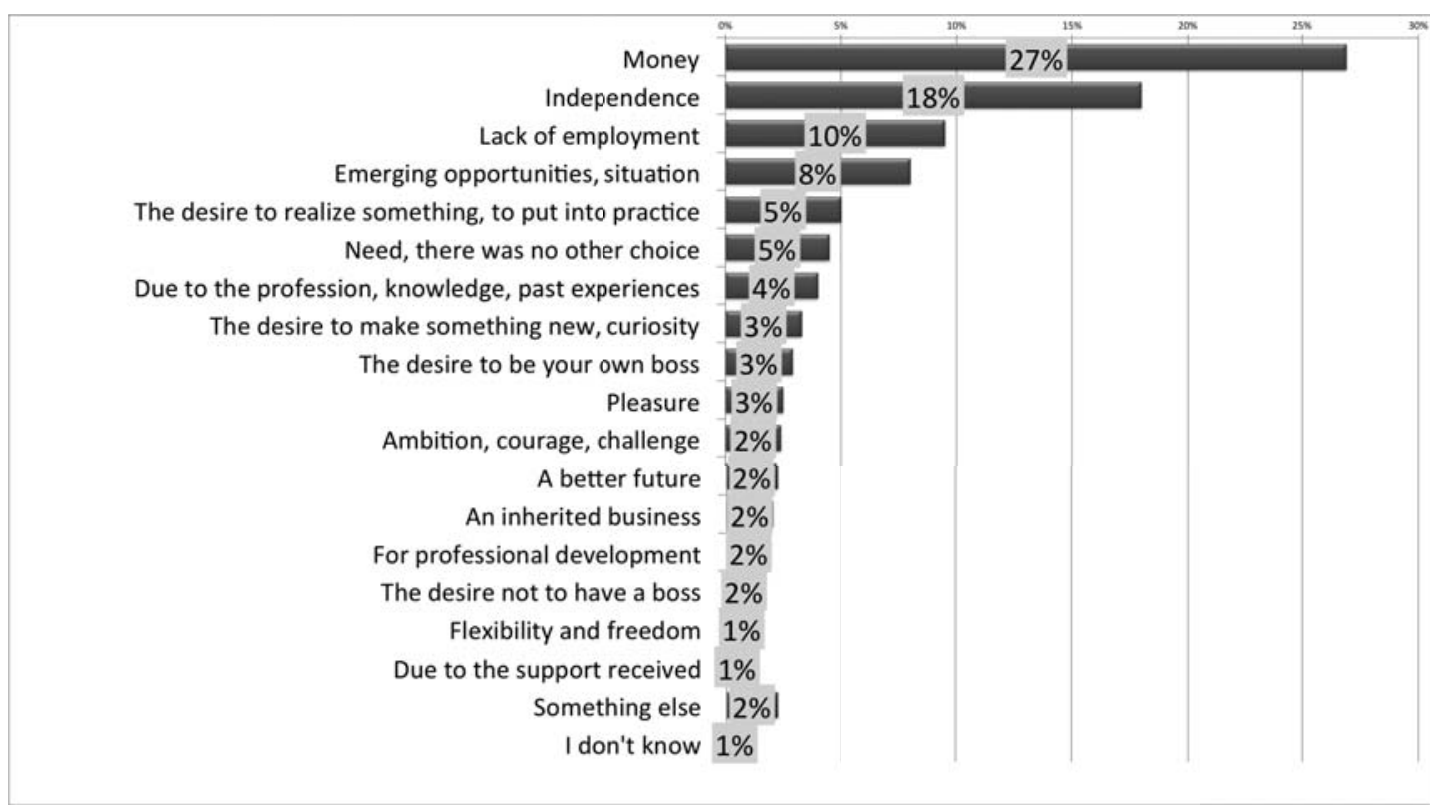

Fig. 5. „What was the main reason for starting a business?"

there is a higher share of businesses started by women after 2005 in the West Region (39\%) and a lower share in the Region of North West. If between 1990 and 1996 there is a higher share of women with secondary education who have started a business, after 2005 women with higher education represent the majority. However, entrepreneurship after 2005 is characterized mainly by the lack of employees.

The motivation for starting a business is extremely varied (Fig. 5). Despite the variety of motivations, there have been identified four categories of determining factors for the women interviewed: accumulation of capital- for $29 \%$ of the respondents; independence, the desire of being their own boss - for $24 \%$ of them; lack of employment, the need - for $14 \%$ and the emergence of an opportunity, occasions - for $11 \%$.

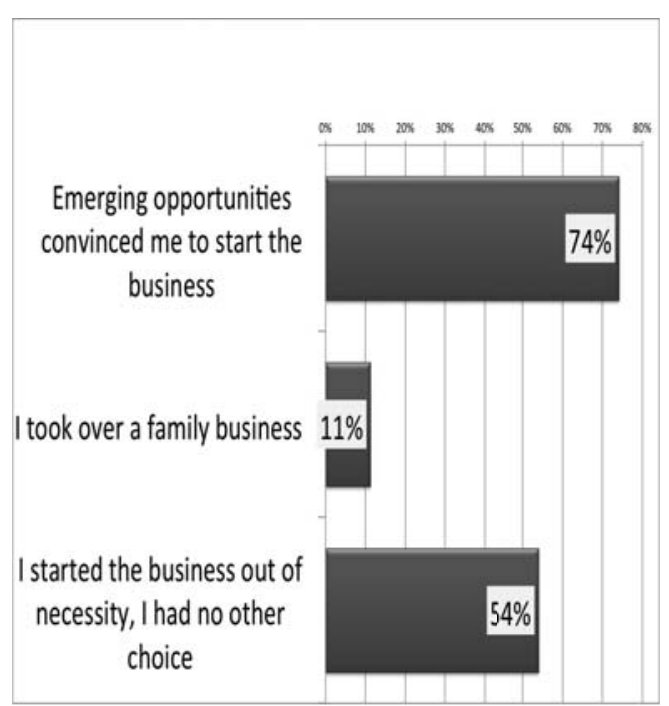

Fig. 6. „Which of the following aspects were true or not when you started your entrepreneurial activity? 
By structuring motivations on three levels - opportunity, continuity and necessity - (Fig. 6) there can be observed low shares for women entrepreneurs who took over a business and significant shares for female entrepreneurs who have speculated an opportunity, but especially for those who have started a business out of necessity. Fragmenting the sample according to the three dimensions, the following percentages have been obtained: $33 \%$ of the respondents have started the business valorising an opportunity but also a necessity; other $33 \%$ of the respondents have started the business only by valorising an opportunity and $14 \%$ of the respondents took this decision only out of necessity. Regarding the context for starting the business, almost half of the respondents (46\%) have started the business alone, and 38\% together with the family (Fig. 7). Friends also represent a reference group when starting a business.

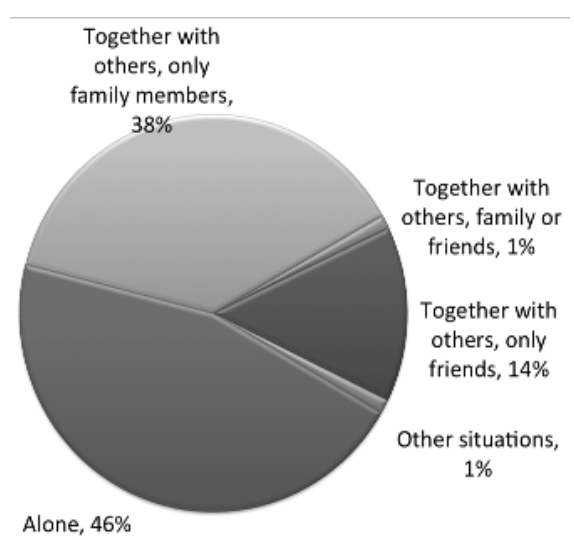

Fig. 7. „How did you start your business, alone or with others?"

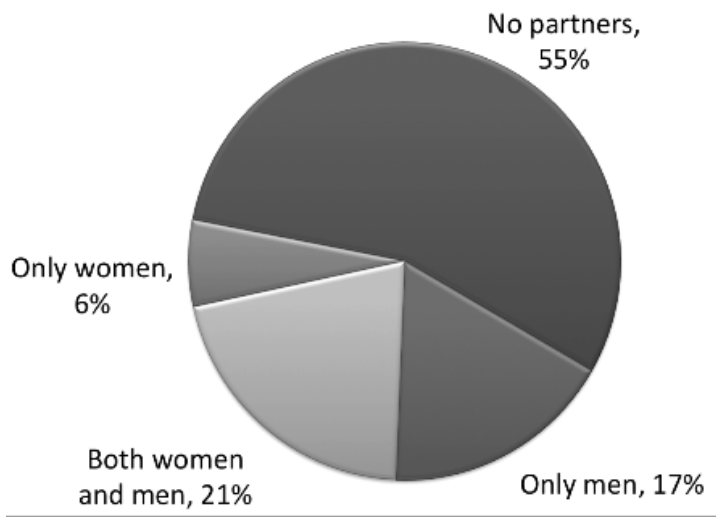

Fig. 8. „Your business partners are....?”
Business partners of women entrepreneurs are $21 \%$ mix partners, both men and women and $17 \%$ only men (Fig. 8). Exclusive female partnership can be found only for $6 \%$ of the respondents, being more accentuated in the Region of West compared with the other regions. A significant share of women, namely $55 \%$ doesn't have business partners, most of these women having higher education. Partnership is more present for companies with over 10 employees, most of those without employees being PFA.

Other aspects analysed were the working schedule and the free time of women entrepreneurs (Fig. 9). Thus, the working schedule is, on average, of 9 hours and a half per day, without significant statistical differences for the three regions.

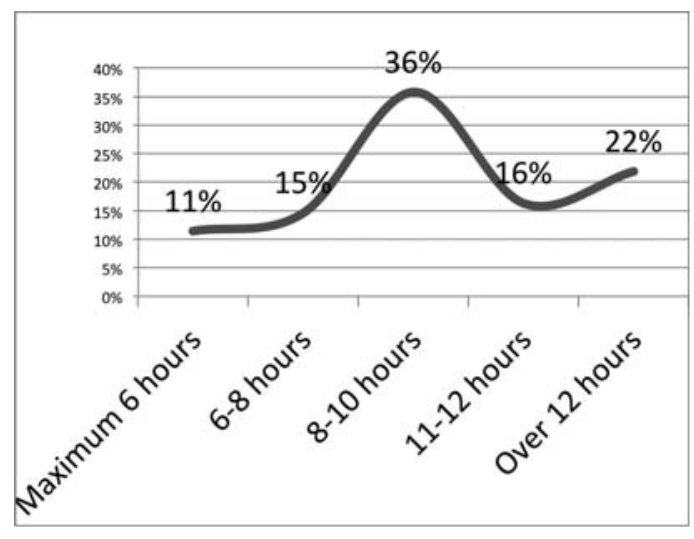

Fig. 9. „Approximately, how many hours you work per day?"

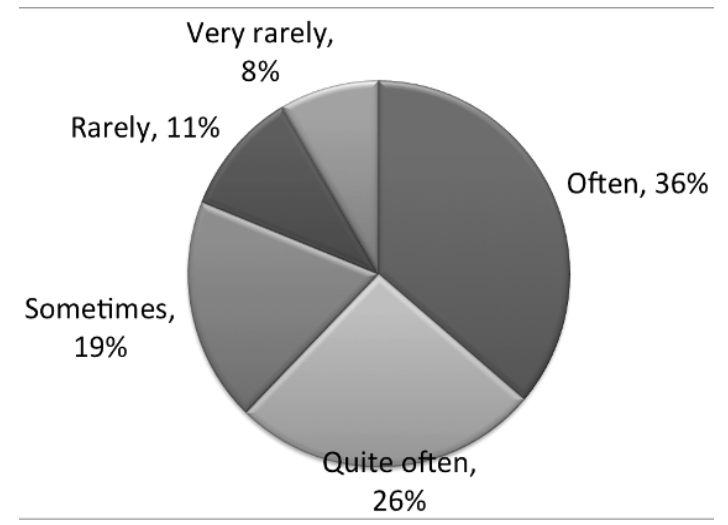

Fig. 10. „How often does it occur to work in the weekend?" 
Women who work on average 10 hours per day are in general those with ages between 41 and 60 and those unmarried. Over a third of the women questioned work often in the weekend, and 26\% of these quite often. Almost 20\% of the women entrepreneurs work rarely, very rarely or not at all on Saturdays and Sundays (Fig. 10). Finding and managing free time is a challenge for the business women interviewed, these women having with an average of 2 hours and a half free per day. Over a third $(36 \%)$ of the women questioned have even less than 2 hours free time per day (Fig. 11).

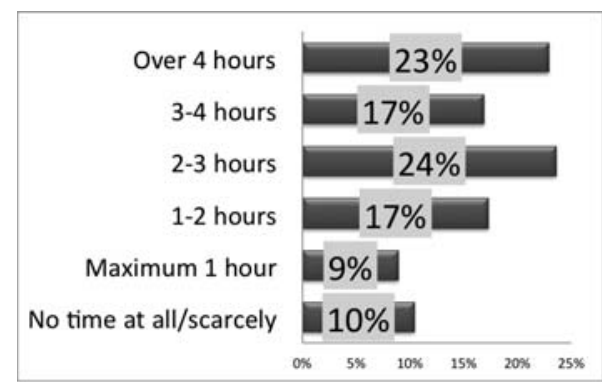

Fig. 11. „How much spare time you have every day?”

The assessment of how these women valorise their free time indicates that approximately $45 \%$ of them have a hobby (Fig. 12 and 13), higher education and high family incomes having a positive influence on the existence of a hobby.

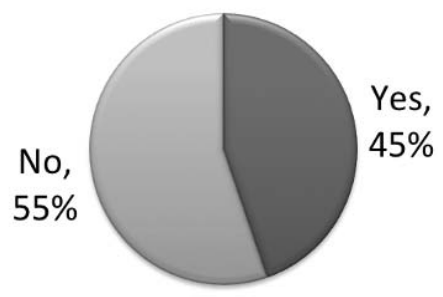

Fig. 12. „Do you have a hobby in your spare time?”

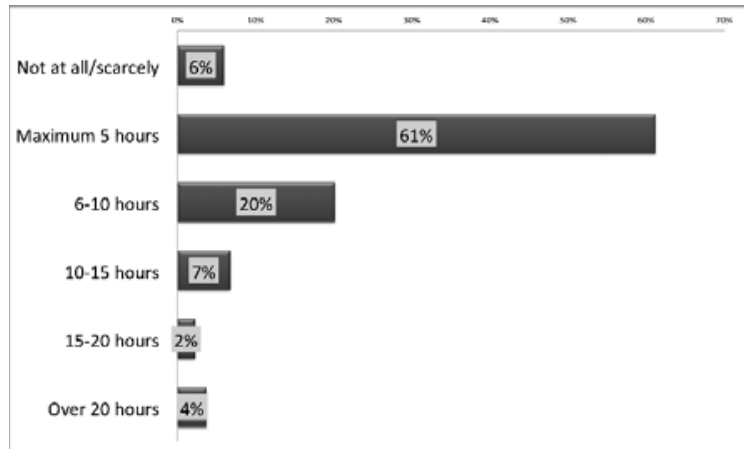

Fig. 13. „If yes. Approximately, how many hours per week you dedicate to your hobby?"
Exploring the inner universe of the businesswoman, her feelings and thoughts, can be observed that, most frequently, a businesswoman feels respect due to her status, she feels that she is successful and that important persons, friends or family, support her in this activity. On the other hand, a businesswoman feels also the stress caused by a heavy work schedule, $30 \%$ of the respondents declaring to feel stressed (Fig. 14).

To a lower extent, of only $16 \%$, women feel guilty for not spending enough time with their family and children. Most of them do not feel all the pressure of others due to the dedication to their business. Different results were obtained by McGowan in a study regarding women entrepreneurs in Northern Ireland, the feeling of guilt for not spending enough time with family and not taking care of children, representing in this situation a barrier in the way of starting a business on their own (McGowan et al, 2012). In a study from North West England it has been identified another factor that inhibits women to start businesses, namely, the lack of specialized services of childcare (Fielden et al., 2003).

By reducing all data to three factors: feelings about the commitment (work, stress, lack of time), those regarding the satisfaction of being a business woman (pride, success, respect) and those on how the relationship with the dear ones is affected (family, children, friends), several conclusions can be reached. There are no differences for the main socio-demographic categories regarding selfperception on work commitment. Businesswomen with secondary education, those with family incomes below 3000 RON and those who don't have employees feel to a lesser degree satisfaction due to their status. Business women not involved in relationships experience a lesser degree the feel of guilt for not spending enough time with their loved ones.

About $20 \%$ of the respondents plan to close their business in the next two years, $11 \%$ intend to sell the business and $7 \%$ to solicit insolvency or bankruptcy (Fig. 15). Of course, some of these situations overlap. If the situations with a low probability are separated, it can be observed that approximately $74 \%$ of the companies surveyed are not, with high probability, in any of the situations described above.

There are no statistically significant differences at a regional level; however, there is a higher 


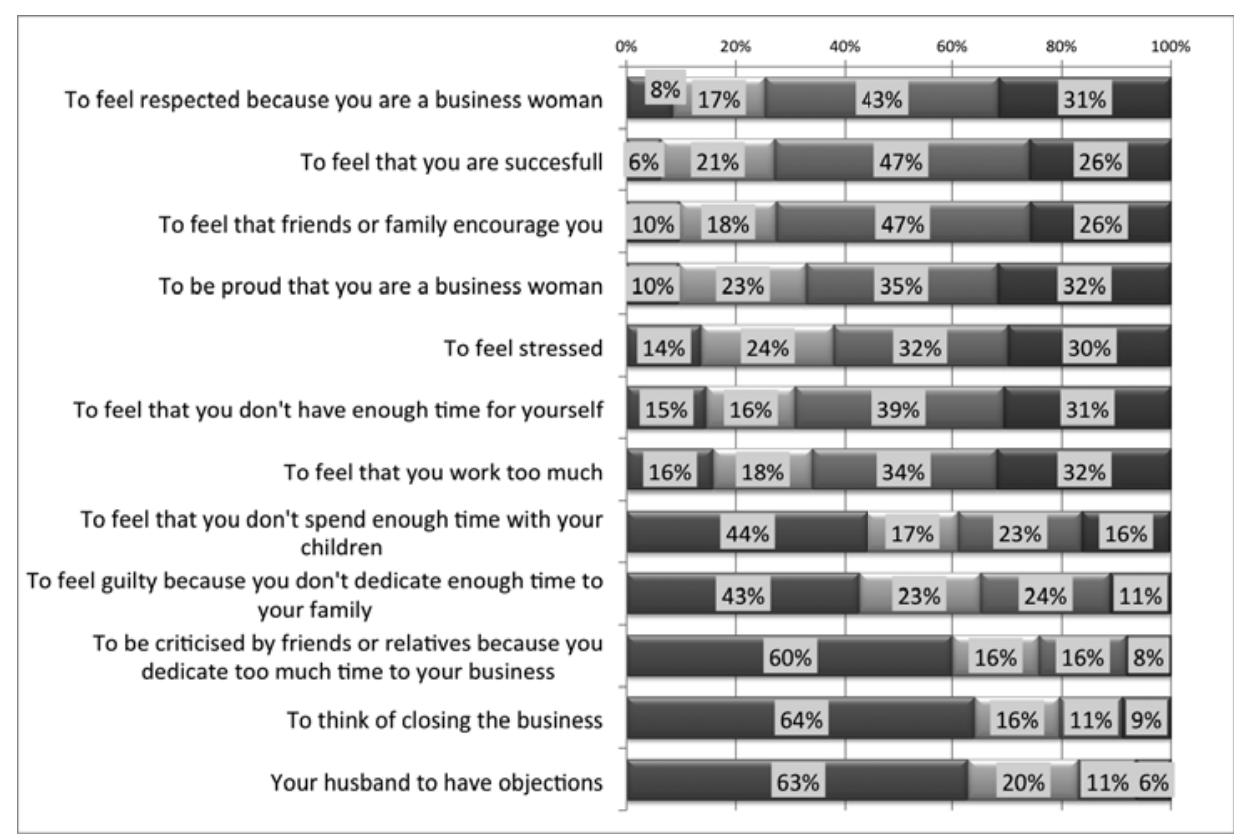

Fig. 14. „How often it happens...?”

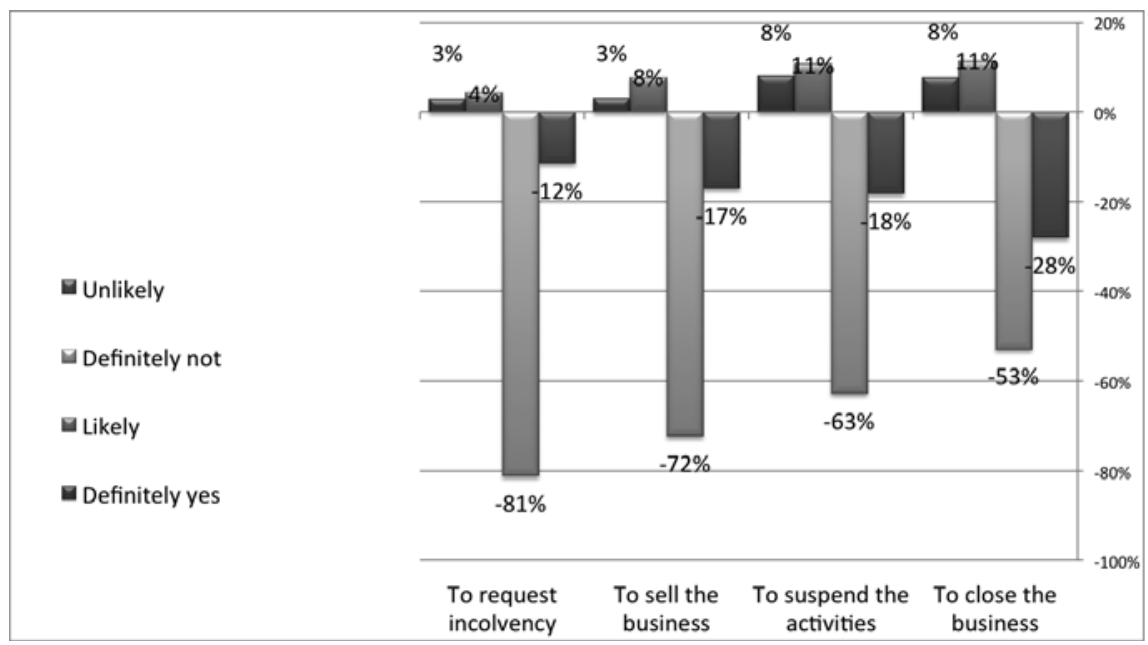

Fig. 15. „In the following 2 years, how likely it is...?”

probability of such situations to occur among women entrepreneurs with secondary education (35\%) compared to those with higher education (21\%). Also, businesses without employees seem to be more affected by closure and bankruptcy (42\% are with high probability in, at least, one of the situations described) than those with employees.

\section{CONCLUSION}

Women entrepreneurs from the area studied are generally satisfied with their decision to start up a business. Entrepreneurship occurs most frequently among women with ages between 25 and 44 , normal occurrence given the fact that it is needed to fulfil a mix of attributes in order to make this step: work power, knowledge, skills, courage and maturity. The start-up of a business by women in Romania was strongly influenced by economic characteristic and socio-political movements for a country in transition. Analysing the evolution of the motivation behind female entrepreneurship over the years, it can be observed an increase of the financial motivation and the one related to financial independence and a decrease in motivation related to necessity and exploitation of 
opportunities. Most businesswomen questioned enjoy the status gained as well as the support of their loved ones, without external pressure or feelings of guilt. Financial stability guaranteed for the family can compensate, apparently, the lack of time spent together with the dear ones.

The originality, the particularity of the research resides in the fact that it has been evaluated women satisfaction regarding the initiative to become entrepreneurs at a regional level, practically highlighting the results of an action started more than 20 years ago, from several points of view: formation of the entrepreneurial culture, institutional structuring and eliminating gender inequalities. The paper offers practical help to women who intent to start a business in the North West, North East and West Regions of Romania. The results of the study represent an important instrument for knowing women's position in the entrepreneurial sector and for monitoring the progress made by women entrepreneurship at a regional level.

It is recommended that to validate the results of the research by extending the study for all the regions in Romania. Another line of research for complementing the results of this research could be to assess the impact of the Multiannual National Program for developing entrepreneurship among women managers on the development of small and medium enterprises.

Acknowledgments. This work was a part of the Grant entitled "An integrated intervention in order to strengthen social entrepreneurship among vulnerable women", Contract POSDRU/84/ $6.1 / \mathrm{S} / 53513$.

\section{REFERENCES}

1. Achtenhagen L, Tillmar M (2013). Studies on women's entrepreneurship from Nordic countries and beyond. International Journal of Gender and Entrepreneurship, 5(1): 4-16.

2. Akehurst G, Simarro E, Mas-Tur A (2012). Women entrepreneurship in small service firms: motivations, barriers and performance. The Service Industries Journal, 32(15): 2489-2505

3. Boone HN, Boone DA (2012). Analyzing likert data. Journal of Extension 50.2: 1-5.

4. Brush CG (1999). Research on women business owners: past trends, a new perspective and future directions, Entrepreneurship Theory \& Practice, 16(4): 5-30.

5. Fielden SL, Davidson MJ, Dawe AJ, Makin PJ (2003) Factors inhibiting the economic growth of female owned small businesses in North West England. Journal of Small Business and Enterprise Development, 10(2): 152-166.

6. Heilbrunn S, Abu-Asbeh K, Nasra MA (2014). Difficulties facing women entrepreneurs in Israel: a social stratification approach. International Journal of Gender and Entrepreneurship, 6(2): 142-162.

7. Hughes KD, Jennings JE, Brush $\mathrm{C}$, Carter $\mathrm{S}$, Welter $\mathrm{F}$ (2012). Extending women's entrepreneurship research in new directions. Entrepreneurship Theory and Practice, 36(3): 429-442.

8. Jennings JE, Brush CG (2013). Research on women entrepreneurs: challenges to (and from) the broader entrepreneurship literature? The Academy of Management Annals 7.1: 663-715.

9. Kautonen T, Tornikoski ET, Kibler E (2011). Entrepreneurial intentions in the third age: the impact of perceived age norms. Small business economics, 37(2): 219-234.

10. McGowan P, Redeker CL, Cooper SY, Greenan K (2012). Female entrepreneurship and the management of business and domestic roles: Motivations, expectations and realities. Entrepreneurship \& Regional Development, 24(1-2): 53-72.

11. On A (2011). Women entrepreneurship in Romania. Romanian Journal of Economics, 33.2 (42): 138-145.

12. Paul S, Sarma V (2013). Economic crisis and female entrepreneurship: Evidence from countries in Eastern Europe and Central Asia (No. 13/08). CREDIT Research Paper.

13. Pena I, (2002). Intellectual capital and business start-up success. Journal of intellectual capital, 3(2): 180-198.

14. Raposo M, Do Paço A (2011). Entrepreneurship education: Relationship between education and entrepreneurial activity. Psicothema, 23(3): 453-457.

15. Vosta LN, Jalilvand MR (2014). Examining the influence of social capital on rural women entrepreneurship: an empirical study in Iran. World Journal of Entrepreneurship, Management and Sustainable Development, 10(3): 4-4.

16. Welter F, Smallbone D (2011). Institutional perspectives on entrepreneurial behavior in challenging environments. Journal of Small Business Management, 49(1): 107-125.

17. Welsh DH, Memili E, Kaciak E, Al Sadoon A (2014). Saudi women entrepreneurs: A growing economic segment. Journal of Business Research, 67(5): 758-762.

18. Welsh DH, Memili E, Kaciak E, Ochi M (2014). Japanese women entrepreneurs: implications for family firms. Journal of Small Business Management, 52(2): 286-305.

19. Zimmerman MA, Chu. HM (2013). Motivation, success, and problems of entrepreneurs in Venezuela. Journal of Management 14.2: 77.

20. *** Global Entrepreneurship Monitor, 2013, http://www. gemconsortium.org/docs/download/3106, last accession date 23 of July 2013.

21. *** Global Entrepreneurship Monitor Women's Report, 2013, http://www.gemconsortium.org/docs/2825/gem2012-womens-report, last accession date 23 of July 2013. 